\title{
PENGARUH PENGGUNAAN TEPUNG EMPING MELINJO (Gnetum gnemon) DALAM PAKAN TERHADAP pH, KADAR AIR, DAN DAYA SUSUT DAGING AYAM KAMPUNG
}

\author{
Yopianus Anamila; Dyah Lestari Yulianti; Aju Tjatur Nugroho Krisnaningsih \\ Fakultas Peternakan,Universitas Kanjuruhan Malang \\ Jl. S. Supriadi No.48 Malang \\ Email: yopianusanamila6218@gmail.com
}

\begin{abstract}
ABSTRAK
Penelitian ini bertujuan untuk mengetahui pengaruh penggunaan tepung emping melinjo (Gnetum gnemon) pada pakan terhadap $\mathrm{pH}$, kadar air, dan penyusutan daging ayam. Dalam percobaan dengan rancangan acak lengkap 4 perlakuan, 4 ulangan, satu unit eksperimen yang terdiri dari 5 ayam ayam yang dibagi secara acak. Keempat ulangan tersebut konsisten dengan empat perlakuan dari penelitian ini, masing-masing mengandung P0, P1, P2, dan P3 adalah $0 \%$ (kontrol), 5\%, 10\%, dan 15\%. Melinjo emping flour (Gnetum gnemon) adalah sebagai pakan tambahan yang didapat dari pasaran. Variabel penelitian adalah: pH, kadar air, dan konsumsi daging ayam. Hasil penelitian menunjukkan bahwa kadar keripik leleh (Gnetum gnemon) tidak berpengaruh terhadap $\mathrm{pH}$ daging $(\mathrm{P}>0,05)$ sedangkan pada kadar air dan penyusutan Daging ayam menunjukkan perbedaan pengaruh yang sangat signifikan $(\mathrm{P}<0,01)$. Nilai $\mathrm{pH}$ rata-rata pada perlakuan P0, P1, P2, dan P3 adalah 5,9; 5.9; 6.0 dan 5.9. Nilai rata-rata kadar air dalam perlakuan P0, P1, P2, dan P3 adalah 79,30; 84,90; 83.30, dan 83.40. Nilai rata-rata penyusutan daging ayam dalam perlakuan P0, P1, P2, dan P3 adalah 2,7; 4.2; 4,7 dan 4,7. Disimpulkan bahwa penambahan pati emping melinjo (Gnetum gnemon) berpengaruh pada kadar air dan penyusutan daging ayam. Namun, penggunaan tepung emping melinjo (Gnetum gnemon) tidak berkaryh pada $\mathrm{pH}$ daging ayam.
\end{abstract}

Kata kunci: emping, melinjo, $\mathrm{pH}$, kadar air, dan daya susut

\begin{abstract}
This study aims to determine the effect of the use of emping melinjo flour (Gnetum gnemon) in feed to $\mathrm{pH}$, moisture content, and shrinkage of chicken meat. In an experiment with a complete randomized design of 4 treatments, 4 replications, one experimental unit consisting of 5 randomly divided chicken chickens. The four replications were consistent with four treatments from the study, each containing P0, P1, P2, and P3 were 0\% (control), 5\%, 10\%, and 15\%. Melinjo emping flour (Gnetum gnemon) is as an additional feed obtained from the market. The research variables were: $\mathrm{pH}$, Water content, and Chicken Meat Meat Consumption. The results showed that the level of using melting chips (Gnetum gnemon) did not give effect to meat $\mathrm{pH}(\mathrm{P}>0,05)$ while in water content and shrinkage Chicken meat showed very significant difference of influence ( $\mathrm{P}$ $<0.01$ ). The mean $\mathrm{pH}$ value at treatment $\mathrm{P} 0, \mathrm{P} 1, \mathrm{P} 2$, and $\mathrm{P} 3$, was 5.9; 5.9; 6.0 and 5.9. The average value of water content in the treatment of P0, P1, P2, and P3 was 79.30; 84.90; 83.30, and 83.40. The mean value of shrinkage of chicken meat in treatment P0, P1, P2, and P3 was 2.7; 4.2; 4.7 and 4.7. It was concluded that the addition of emping melinjo starch (Gnetum gnemon) had an effect on water content and shrinkage of chicken meat. However, the use of emping melinjo flour (Gnetum gnemon) is not berkaryh at the $\mathrm{pH}$ of chicken meat.
\end{abstract}

Key words: mash; belinjo; $\mathrm{pH}$; moisture content; shrinkage meet.

\section{Pendahuluan}

Keberhasilan usaha peternakan unggas dipengaruhi oleh tiga faktor, yaitu: bibit, pakan, dan manajemen pemeliharaan. Penyediaan ransum yang berkualitas ternyata masih menemui banyak kendala sampai saat ini karena sebagian bahan baku pakan masih diperoleh melalui mekanisme impor yang sangat dipengaruhi oleh ketersediaan dan harga 
yang fluktuatif. Biaya pakan dalam budaya unggas menempati porsi terbesar dari total biaya, yaitu sekitar 70-80\%. Berdasarkan data yang dirilis oleh Departemen Pertanian RI jumlah bahan pakan yang diperoleh secara impor, yaitu: jagung 51,4\%, bungkil kedelai 18\%, tepung ikan 5\%, Corn Gluten Meal (CGM) 7,0\%, premix 0,6\%, dan Crude Palm Oil (CPO) 2\%, dan selebihnya dedak (Ditjennak, 2010). Upaya untuk mengatasi masalah tersebut dapat dilakukan dengan mencari bahan baku alternatif yang murah, mudah didapat, mempunyai nilai kandungan nutrisi tinggi, penggunaan tidak bersaing dengan kebutuhan manusia dan mempunyai pengaruh yang baik pada ternak.

Salah satu bahan pakan alternatif (non-konvensional) yang memiliki harga relatif lebih murah dapat berasal dari limbah (by-product) pertanian dan industri. Salah satu tanaman hortikultura yang memiliki potensi besar untuk dikembangkan adalah melinjo (Gnetum genemon). Tanaman melinjo di beberapa daerah selain sebagai penghasil tanaman sayuran melinjo juga merupakan sumber bahan baku pembuatan emping melinjo. Emping melinjo merupakan salah satu bahan makanan ringan, selain bernilai gizi tinggi emping melinjo juga memiliki cita rasa yang banyak disukai masyarakat. Emping melinjo merupakan makanan istimewa dalam pola makanan rakyat Indonesia. Kandungan gizi dan vitamin yang terdapat dalam makanan yang berasal dari emping melinjo meliputi ; kalori, karbohidrat, protein, lemak, kalsium, fospor, besi, vitamin B, dan lemak siklopropen (cyclopropene fatty acid) (Aliudin dan Anggraeni, 2012).

Industri skala rumah tangga yang mengolah emping melinjo banyak ditemukan di Jawa Tengah dan Jawa Timur Limbah yang dihasilkan dari industri pengolahan emping melinjo tersebut adalah produk afkir proses pengolahan biji melinjo menjadi emping yang hancur akibat proses penumbukan. Limbah tersebut sedianya sudah dimanfaatkan oleh beberapa peternak sebagai bahan pakan untuk ternak unggas, namun publikasi hasil studi empiris yang bersifat ilmiah belum ditemukan.

Bahan pakan ternak unggas dibagi menjadi dua kelompok, yaitu bahan pakan sumber energi dan bahan pakan sumber protein. Konsentrat adalah suatu bahan makanan yang dipergunakan bersama bahan pakan lain untuk meningkatkan keserasian gizi dari keseluruhan makanan dan dimaksudkan untuk disatukan dan dicampur sebagai suplemen (pelengkap) atau makanan lengkap (Hartadi, Reksohadiprodjo, dan Tillman 2005). Kualitas bahan pakan yang baik, tentunya menghasilkan kaulitas daging yang baik pula. Kualitas daging ayam dapat di tentukan oleh $\mathrm{pH}$, kadar air dan daya susut daging.

Berdasarkan uraian diatas sehingga diperlukan penelitian yang bertujuan untuk mengetahui potensi tepung emping melinjo sebagai bahan pakan penyusun ransum ternak ayam kampung. 


\section{Materi dan Metode}

Materi yang digunakan dalam penelitian ini adalah:

1. DOC ayam kampung sebanyak 80 ekor. DOC ayam kampung diperoleh dari usaha pembibitan ayam kampung C.V. Panca Murti, Kelurahan Tlogomas, Kota Malang.

2. Bahan pakan penyusun ransum yang terdiri atas: jagung, dedak, konsentrat ayam pedaging (kode pakan: CP 511 produksi PT. Charoen Pokphand Indonesia),

3. Tepung emping melinjo yang diperoleh dari industri pengolahan emping melinjo di Sidoarjo. Pakan penelitian diformulasikan berdasar kebutuhan nutrisi ayam kampung. Pakan dan air minum diberikan secara ad libitum. Formulasi pakan penelitian disajikanpada Tabel 1.

4. Air minum diberikan secara ad libitum

Tabel 1. Formulasi pakan penelitian

\begin{tabular}{lrrrr}
\hline \multirow{2}{*}{ Bahan pakan } & \multicolumn{4}{c}{ Persentase (\%) } \\
\cline { 2 - 5 } & \multicolumn{1}{c}{$\mathrm{P}_{0}$} & \multicolumn{1}{c}{$\mathrm{P}_{2}$} & \multicolumn{1}{c}{$\mathrm{P}_{3}$} \\
\hline Dedak halus & $26,2 \%$ & $26,2 \%$ & $26,2 \%$ & $26,2 \%$ \\
Tepung emping melinjo & $0,0 \%$ & $5,0 \%$ & $10,0 \%$ & $15,0 \%$ \\
Konsentrat & $23,1 \%$ & $18,1 \%$ & $13,1 \%$ & $8,1 \%$ \\
Jagung giling & $50,8 \%$ & $50,8 \%$ & $50,8 \%$ & $50,8 \%$ \\
Vitamin dan mineral & Additive & Additive & Additive & Additive \\
\hline
\end{tabular}

Tabel 2. Kandungan Zat Makanan Dan Komposisi Bahan Pakan

\begin{tabular}{|c|c|c|c|c|c|c|c|c|c|c|}
\hline \multirow{2}{*}{$\begin{array}{l}\text { Bahan } \\
\text { pakan }\end{array}$} & \multicolumn{6}{|c|}{ Kandungan Zat Makanan } & \multicolumn{4}{|c|}{ Komposisi Bahan Pakan } \\
\hline & $\begin{array}{l}\mathrm{BK}( \\
\%)\end{array}$ & $\begin{array}{l}\text { EM(kkal/ } \\
\mathrm{kg})\end{array}$ & $\begin{array}{l}\mathrm{PK}( \\
\%)\end{array}$ & $\begin{array}{l}\text { SK( } \\
\%)\end{array}$ & $\begin{array}{l}\mathrm{LK}( \\
\%)\end{array}$ & $\begin{array}{l}\text { Abu( } \\
\%)\end{array}$ & P0 & P1 & P2 & P3 \\
\hline $\begin{array}{l}\text { Jagung } \\
\text { giling }^{1}\end{array}$ & 86,00 & $2.690,00$ & 8,90 & 2,20 & 4,00 & 1,70 & $\begin{array}{r}50,80 \\
\%\end{array}$ & $\begin{array}{r}50,80 \\
\%\end{array}$ & $\begin{array}{r}50,80 \\
\%\end{array}$ & $\begin{array}{r}50,80 \\
\%\end{array}$ \\
\hline $\begin{array}{l}\text { Dedak } \\
\text { halus }^{1}\end{array}$ & 86,00 & $2.730,00$ & $\begin{array}{r}11,9 \\
0\end{array}$ & $\begin{array}{r}10,0 \\
0\end{array}$ & $\begin{array}{r}12,1 \\
0\end{array}$ & 10,10 & $\begin{array}{r}26,20 \\
\%\end{array}$ & $\begin{array}{r}26,20 \\
\%\end{array}$ & $\begin{array}{r}26,20 \\
\%\end{array}$ & $\begin{array}{r}26,20 \\
\%\end{array}$ \\
\hline $\begin{array}{l}\text { Konsentr } \\
\mathrm{at}^{2}\end{array}$ & 88,00 & $2.800,00$ & $\begin{array}{r}32,0 \\
0 \\
\end{array}$ & 6,00 & $\overline{6,00}$ & 7,00 & $\begin{array}{r}23,00 \\
\% \\
\end{array}$ & $\begin{array}{r}18,00 \\
\% \\
\end{array}$ & $\begin{array}{r}13,00 \\
\% \\
\end{array}$ & $\begin{array}{r}8,00 \\
\% \\
\end{array}$ \\
\hline $\begin{array}{l}\text { Tepung } \\
\text { emping } \\
\text { melinjo }^{3}\end{array}$ & 90,71 & $2.872,92$ & $\begin{array}{r}10,4 \\
7\end{array}$ & 1,53 & 1,53 & 2,71 & $\begin{array}{r}0,00 \\
\%\end{array}$ & $\begin{array}{r}5,00 \\
\%\end{array}$ & $\begin{array}{r}10,00 \\
\%\end{array}$ & $\begin{array}{r}15,00 \\
\%\end{array}$ \\
\hline
\end{tabular}

Keterangan:

${ }^{1}$ Tabel komposisi bahan pakan Hari Hartadi (2000)

${ }^{2}$ Label pakan

${ }^{3}$ Hasil analisis laboratorium Nutrisi dan Takanan Ternak UB

\begin{tabular}{|l|r|r|r|r|}
\hline Kandungan energy nutrisi & P0 & P1 & P2 & P3 \\
\hline EM(kkal/kg) & 2,73 & 2,73 & 2,73 & 2,73 \\
\hline BK(\%) & 8,64 & 8,65 & 8,68 & 8,67 \\
\hline PK(\%) & 14,99 & 13,92 & 12,85 & 11,77 \\
\hline LK(\%) & 6,59 & 6,36 & 6,14 & 5,92 \\
\hline SK(\%) & 5,12 & 4,93 & 4,74 & 4,55 \\
\hline Abu(\%) & 5,12 & 4,91 & 4,70 & 4,48 \\
\hline
\end{tabular}


Metode yang digunakan dalam penelitian ini adalah percobaan biologis. Rancangan percobaan penelitian adalah Rancangan Acak Lengkap (RAL), jumlah perlakuan 4,masing-masing perlakuan diulang 4 kali meliputi:

$\mathrm{P}_{0}$ : Penggunaan tepung emping melinjo dalam pakan sebesar 0\% (kontrol)

$\mathrm{P}_{1}$ : Penggunaan tepung emping melinjo dalam pakan sebesar 5\%

$\mathrm{P}_{2}$ : Penggunaan tepung emping melinjo dalam pakan sebesar $10 \%$

$\mathrm{P}_{3}$ : Penggunaan tepung emping melinjo dalam pakan sebesar $15 \%$

Data yang diperoleh ditabulasi dan dilanjutkan dengan analisis statistik sidik ragam (ANOVA), jika ditemukan perbedaan antara perlakuan maka dilanjutkan dengan uji jarak Duncan.

\section{Hasil Dan Pembahasan}

Pengaruh perlakuan terhadap rata-rata $\mathrm{pH}$, kadar air,dan daya susut daging ayam kampung di sajikan pada Tabel 4.

Tabel 4. Pengaruh perlakuan terhadap rata-rata $\mathrm{pH}$, kadar air,dan daya susut daging ayam kampung

\begin{tabular}{ccccc}
\hline Perlakuan & $\mathrm{pH}$ & Kadar Air $(\%)$ & $\mathrm{BK}(\%)$ & Daya Susut \\
\hline P0 & $5,9 \pm 0,16$ & $79,30 \pm 0,82^{\mathrm{a}}$ & $20,70 \pm 0,82^{\mathrm{a}}$ & $2,7 \pm 0,16^{\mathrm{a}}$ \\
P1 & $5,9 \pm 0,16$ & $84,90 \pm 0,82^{\mathrm{b}}$ & $15,10 \pm 0,82^{\mathrm{b}}$ & $4,2 \pm 0,16^{\mathrm{b}}$ \\
P2 & $6,0 \pm 0,16$ & $83,30 \pm 0,82^{\mathrm{b}}$ & $16,70 \pm 0,82^{\mathrm{b}}$ & $4,7 \pm 0,16^{\mathrm{c}}$ \\
P3 & $5,9 \pm 0,16$ & $83,40 \pm 0,82^{\mathrm{b}}$ & $16,60 \pm 0,82^{\mathrm{b}}$ & $4,7 \pm 0,16^{\mathrm{c}}$ \\
Sig. & 0,77 & 0,00 & 0,00 & 0,00 \\
\hline
\end{tabular}

Keterangan :Nilai rata-rata dengan superscript yang berbeda pada kolam yang sama menunjukan perbedaan yang sangat nyata $(p>0.01)$

\section{Pengaruh Penggunaan Tepung Emping Melinjo (Gnetum gnemon) Terhadap pH Daging Ayam Kampung}

Hasil penelitian menunjukkan bahwa level penggunaan tepung emping melinjo (Gnetum gnemon) tidak memberikan pengaruh terhadap $\mathrm{pH}$ daging $(\mathrm{P}>0.05)$.Penggunaan tepung emping melinjo memberikan perbedaan kandungan protein pakan perlakuan. Berdasarkan hasil penelitian, rata-rata nilai $\mathrm{pH}$ pada perlakuan $\mathrm{P} 0, \mathrm{P} 1, \mathrm{P} 2$, dan $\mathrm{P} 3$, adalah 5,$9 ; 5,9 ; 6,0$, dan 5,9. Nilai $\mathrm{pH}$ tersebut masih relatif normal, sesuai pernyataan Niewiarowicz (1997) yang menyatakan bahwa pH daging adalah 5,9-6,2. Faktor yang mempengaruhi nilai $\mathrm{pH}$ adalah fisik dan kimia (Poltowicz, 2000). Hasil penelitian menunjukkan bahwa perlakuan tidak memberikan pengaruh terhadap $\mathrm{pH}$ daging, hal ini sesuai dengan penelitian Barteczko dan Lasek (2008) yang menunjukkan tidak terdapat 


\section{Jurnal Sains Peternakan}

Vol 6 No 2, Desember 2018, 16-23

ISSN 2579-4450

perbedaan $\mathrm{pH}$ daging karena pengaruh tingkat energi yang bervariasi dalam pakan broiler.

Banyak faktor yang dapat mempengaruhi $\mathrm{pH}$ daging seperti yang dikemukakan oleh Smith (1978) dan Judge (1989) Stres sebelum pemotongan, seperti iklim, tingkah laku agresif diantara ternak atau gerakan yang berlebihan, juga mempunyai pengaruh yang besar terhadap penurunan atau habisnya glikogen otot dan akan menghasilkan daging yang gelap dengan $\mathrm{pH}$ yang tinggi (lebih besar dari 5,9). Nilai $\mathrm{pH}$ daging ini perlu diketahui karena $\mathrm{pH}$ daginga akan menentukan tumbuh dan berkembangnya bakteri. Hampir semua bakteri tumbuh secara optimal pada pH sekitar 7 dan tidak akan tumbuh persis dibawah $\mathrm{pH} 4$ atau diatas 9, tetapi $\mathrm{pH}$ untuk pertumbuhan optimal ditentukan oleh kerja stimulan dari berbagai variabel lain di luar faktor keasaman itu sendiri (Lawrie, 1979).

\section{Pengaruh Penggunaan Tepung Emping Melinjo (Gnetum gnemon) Terhadap Kadar air dan BK (Bahan Kering) Daging Ayam Kampung}

Hasil penelitian menunjukkan bahwa level penggunaan tepung emping melinjo (Gnetum gnemon) menunjukkan perbedaan pengaruh yang sangat nyata $(\mathrm{P}<0,01)$ terhadap kadar air daging ayam kampung. Penggunaan tepung emping melinjo memberikan perbedaan kandungan protein pakan perlakuan. Hal tersebut memberikan dampak terhadap suplai zat makanan bagi ternak percobaan. Berdasarkan hasil penelitian, rata-rata nilai kadar air pada perlakuan P0, P1, P2, dan P3, adalah 79,30\%; $84,90 \%$; 83,30\%, dan 83,40\%. Sesuai dengan pendapat Pedersen, 1971 di dalam Soeparno (2005) yang menyatakan banyak faktor yang mempengaruhi kadar air daging, diantaranya $\mathrm{pH}$, bangsa, pembentukan aktomiosin (rigormortis), temperatur dan kelembaban, pelayuan karkas, tipe daging dan lokasi otot, fungsi otot, umur, pakan, dan lemak intramuskuler. Kualitas nutrisi pakan sangat mempengaruhi kualitas derivate produk ternak, termasuk daging meliputi kandungan protein, lipida, karbohidrat, dan beberapa senyawa esensial lainnya seperti vitamin, mineral makro, dan mineral makro. Zat makanan tersebut terkandung dalam bahan kering yang terkandung dalam pakan. Semakin tinggi penggunaan tepung emping melinjo dalam pakan maka kandungan protein pakan semakin menurun. Hal tersebut memberikan dampak terhadap kandungan bahan kering daging. Rata-rata kandungan bahan kering perlakuan P0, P1, P2, dan P3 masing-masing adalah $20,70 \% ; 15,10 \% ; 16,70 \%$ dan $16,60 \%$. 


\section{Pengaruh Penggunaan Tepung Emping Melinjo (Gnetum gnemon) Terhadap Daya Susut Daging}

Hasil penelitian menunjukkan bahwa level penggunaan tepung emping melinjo (Gnetum gnemon) menunjukkan perbedaan pengaruh yang sangat nyata $(\mathrm{P}<0,01)$ terhadap daya susut daging. Penggunaan tepung emping melinjo memberikan perbedaan kandungan protein pakan perlakuan. . Berdasarkan hasil penelitian, rata-rata nilai daya susut daging pada perlakuan P0,P1,P2, dan P3, adalah 2,7; 4,2; 4,7, dan 4,7. Susut masak dapat dipengaruhi oleh $\mathrm{pH}$, panjang sarkomer serabut otot, panjang potongan serabut otot, status kontraksi miofibril, ukuran dan berat sampel daging serta penampang lintang daging (Soeparno, 2005). Besarnya susut masak dipengaruhi oleh banyaknya kerusakan membran seluler, banyaknya air yang keluar dari daging, umur simpan daging, degradasi protein dan kemampuan daging untuk mengikat air (Shanks et al., 2002).

Lawrie (2003) menyatakan bahwa jumlah cairan yang diperoleh dalam pemanasan akan meningkat lebih lanjut pada suhu antara $107^{\circ} \mathrm{C}$ dan $155^{\circ} \mathrm{C}$. Hal ini mungkin menggambarkan beberapa kerusakan protein, dengan kerusakan asam-asam amino yang akan terjadi dalam kisaran suhu tersebut. Susut masak dapat digunakan untuk meramalkan jumlah kandungan cairan dalam daging masak. Daging yang mempunyai susut masak yang rendah mempunyai kualitas fisik yang relatif lebih baik dari pada daging dengan susut masak yang lebih besar, karena kehilangan nutrisi selama pemasakan lebih sedikit.

Kualitas nutrisi pakan sangat mempengaruhi kualitas derivate produk ternak, termasuk daging meliputi kandungan protein, lipida, karbohidrat, dan beberapa senyawa esensial lainnya seperti vitamin, mineral makro, dan mineral makro (Tougan et al., 2013), Zat makanan tersebut terkandung dalam bahan kering yang terkandung dalam pakan. Semakin tinggi penggunaan tepung emping melinjo dalam pakan maka kandungan protein pakan semakin menurun. Hal tersebut memberikan dampak terhadap kandungan bahan kering daging. Daging dengan kandungan bahan kering rendah memiliki potensi daya susut yang tinggi. Hal ini sesuai dengan hasil penelitian, dimana rata-rata daya susut daging P0, P1, P2, dan P3 masing-masing adalah 2,7; 4,2; 4,7, dan 4,7.

\section{Kesimpulan}

Berdasarkan hasil penelitian dapat disimpulkan bahwa penambahan tepung emping melinjo (Gnetum gnemon) berpengarug pada Kadar Air,Daya Susut daging dan BK. Namun penggunaan tepung emping melinjo (Gnetum gnemon) sampai dengan level $15 \%$ tidak berpengaru pada $\mathrm{pH}$ daging ayam kampong. 


\section{Ucapan Terimakasih}

Ucapan terima kasih disampaikan kepada semua pihak terutama Laboratorium Lapang Fakultas Peternakan Universitas Kanjuruhan Malang yang telah banyak membantu sejak persiapan hingga terselenggaranya penelitian ini dengan baik.

\section{Daftar Pustaka}

Afria, 2013. Effect of Addition of Choline Chloride in Feed on Quail (Coturnix coturnix Japonica). Production Performance. Fakultas Peternakan. Universitas Brawijaya.

Anggorodi, R. 1994. Ilmu Makanan Ternak Umum. PT. Gramedia. Jakarta.

Aliudin dan D. Anggraeni, 2012. Nilai Tambah Emping Melinjo Melalui Teknologi Produksi Konvensional di Desa Menes Kecamatan Menes Kabupaten Pandeglang. Agrika Vol 6 No.1

Aviagen, 2011. Optimizing Broiler Feed Convertion Ratio. Tech. Notes. Ross an Aviagen Brand.

Bhat R., and N. Yahya, 2014. Evaluating Belinjau (Gnetum gnemon L.) Seed Flour Quality as Base for Development of Novel Product and Food Formulation. Food Chem. (156)42-9. Doi: 10.1016/j.foodchem.2014.01.063

Ditjennak, 2010. Statistika Peternakan. Direktorat Jenderal Peternakan. Kementerian Pertanian. Jakarta. 287 hal.

Diwyanto K., D. Zainuddin, T. Sartika, S. Rahayu, Djufri, C. Arifin, dan Cholil. 1996. Model Pengembangan Agribisnis. Komoditi Ternak Buras. Laporan Dirjennak bekerjasama dengan Balitnak.

Iskandar S., 2005. Strategi Pengembangan Ayam Lokal. Wartazoa, 16(4): 191-197

Manner H.I, and C.R. Elevitch, 2006. Gnetum gnemon (gnetum). Species Profiles for Pacific Island Agroforestry. www.traditionaltree.org

NRC, 1994. Nutrient Requirement of Poultry: Ninth Revised Edition. National Research Council. National Academy Press. Washington D.C.

Sartika T.B., R. Gunawan, Matondang dan P. Mahyudin, 2002. Seleksi Generasi Ketiga untuk Mengurangi Sifat Mengeram dalam Meningkatkan Produksi Telur Ayam Lokal. Laporan No. UAT/BRE/F.01/APBN/2001. Balai Penelitian Ternak. Bogor. Hal 1-9.

Siswoyo T.A., 2014. Fakta Melinjo Berkhasiat Obat. Trubus. http://www.trubusonline.co.id/fakta-melinjo-berkhasiat-obat/. Diakses tanggal 20 Pebruari 2017.

Shabrina A.U., Eko W., dan. M.H. Natsir., 2014. Efek Suplementasi Betain dalam Pakan Rendah Metionin Terhadap Penampilan Produksi Itik Mojosari Jantan. J. Nutrisi Ternak Vol.1 No.1: 27-33 


\section{Jurnal Sains Peternakan}

Vol 6 No 2, Desember 2018, 16-23

ISSN 2579-4450

Sulandri S.,M.S.A. Zein, S. Paryati dan T. Sartika., 2007. Taksonomi dan Asal-Usul Ayam Domestikasi Dalam: Keanekaragaman Sumber Daya Hayati Alam Lokal Indonesia: Manfaat dan Potensi. Diwyanto K., and Prijono S.N. (Eds). Pusat Penelitian Biologi. Lembaga Ilmu Pengetahuan Indonesia. Bogor. 25 hal.

Tillman, A.D., H. Hartadi, S. Reksohadiprodjo, S. Prawirokusumo, dan S. Lebdosoekojo. 1991. Ilmu Makanan Ternak Dasar. Cetakan kelima. Gadjah Mada University Press, Yogyakarta.

Wahyu J., 2004. Ilmu Nutrisi Unggas. Yogyakarta. Gadjah Mada University Press.

Winendar H., S. Listyawati, and Sutarto, 2006. Daya Cerna Protein Pakan dan Pertambahan Berat Badan Ayam Broiler setelah Pemberian Pakan yang Difermentasi dengan Effective Microorganisms-4 (EM-4). Bioteknologi 3(1): 1419. Doi: $10.13057 /$ biotek/c030103

Sutopo, Lita. 2004. Teknologi Benih. Fakultas pertanian Universitas Brawijaya. Malang.

Yunita, R. 2011. Pengaruh Pemberian Urine Sapi, Air Kelapa, dan Rootone F Terhadap Pertumbuhan Setek Tanaman Markisa (Passiflora edulis var. Flavicarpa). Solok. Hal 1-10. 